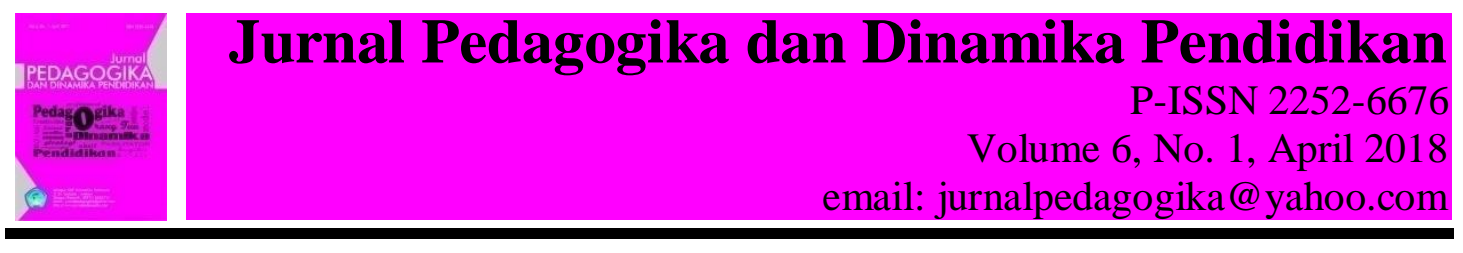

\title{
PENDEKATAN KONSTRUKTIVIS SOSIAL DALAM PENINGKATAN HASIL BELAJAR IPS DI SD KELAS IV
}

\author{
Elsinora Mahananingtyas \\ Dosen pada Program Studi Pendidikan Guru Sekolah Dasar \\ Universitas Pattimura-Maluku
}

\section{ARTICLE INFO}

Article History:

Accepted 20-03-2018

Available online 23-04-2018

Keywords:

a social Constructivist

Approach, social context

\begin{abstract}
Learners at elementary school age generally have a concept that is rich, but not systematically, not organized and spontaneous. With a skilled supervisor dialogue together, then learners can develop the concepts that are more systematic, logical, and rational. A social constructivist approach stresses the social context in learning that knowledge is constructed and built together with the teacher or friend of the more skilled colleagues. The purpose of this research is to improve or enhance quality (quality) were learning in class by applying the social constructivist approach at grade IV in the primary Christian Advent of Ambon. The method of this research is a type of class action Research with 4 stages, namely planning, implementation, observation and reflection. The results of this research that is happening gradual classical on the learners of the cycle I meeting 1 to 2 meetings amounted to $6.6 \%$ of the cycle I of the meeting 1 of $59 \%$ to $65.6 \%$ in meeting 2. While the ketuntasan of classical learners on cycle II increased to $6.8 \%$ in cycle II meeting 1 of $77.2 \%$ to $84 \%$. Cycle II whole learners, prepared with a value above the KKM i.e. 15 learners or $100 \%$ complete.
\end{abstract}

\section{PENDAHULUAN}

Proses belajar mengajar merupakan proses interaksi yang dilakukan antara guru dan peserta didik dalam suatu pembelajaran untuk mencapai tujuan dalam kurikulum yang telah ditetapkan. Guru menggunakan berbagai alternatif dalam pembelajaran seperti menggunakan beberapa metode dan model pembelajaran yang disesuaikan dengan situasi dan kondisi dalam pembelajaran. Sehingga dapat menciptakan suatu situasi pengajaran yang menyenangkan dan mendukung bagi proses belajar mengajar dan tercapainya prestasi belajar peserta didik yang memuaskan. 
Pada saat ini penerapan Kurikulum Tingkat Satuan Pendidikan (KTSP) yang sudah terlaksana di seluruh sekolah di Indonesia dan juga Kurikulum 2013 yang baru diselenggarakan di beberapa sekolah di Indonesia menuntut adanya pengembangan indikator dari para guru berdasarkan standar kompetensi dan kompetensi dasar yang telah ada. Hal ini berdampak pula pada kompetensi dan kemandirian peserta didik dalam situasi pembelajaran. Kompetensi di sini adalah kemampuan dasar dari setiap peserta didik untuk tidak sekedar menyerap informasi dan pelajaran tetapi juga mengaplikasikan informasi itu dalam dunia nyata yang lebih kontekstual, sedangkan kemandirian adalah kemampuan dasar setiap peserta didik untuk belajar, berkreasi dan berinovasi terhadap informasi dan pelajaran. Sebagai contoh, metode diskusi akan berusaha mengoptimalkan kompetensi dan kemandirian peserta didik. Peserta didik dapat belajar mengemukakan pendapat dan juga bertukar pikiran dengan peserta didik yang lain. Hal itu memudahkan peserta didik untuk mengembangkan dan menambah pengetahuan yang telah dimilikinya.

Berdasarkan hasil observasi yang dilaksanakan di kelas IV SD Kristen Advent Ambon, bahwa dalam pembelajaran IPS materi Permasalahan Sosial banyak peserta didik yang nilai ulangan hariannya masih dibawah standar KKM yaitu 65, terbukti dari 15 peserta didik yang ada di kelas IV hanya 6 orang saja yang tuntas di atas KKM nilainya. Dalam pembelajaran IPS juga masih terlihat guru memberikan ceramah tentang permasalahan sosial setelah itu guru memberikan soal untuk dikerjakan masing-masing individu lalu dikumpulkan. Hal ini menunjukkan bahwa metode diskusi masih jarang dilakukan di kelas tersebut. Padahal metode diskusi sangat penting bagi peserta didik dalam mengembangkan pengetahuan awalnya untuk menambah informasi yang baru. Peserta didik juga terlihat pasif menerima materi pelajaran, hal ini terlihat banyak peserta didik yang mengantuk karena mendengarkan guru memberikan materi sangat lama.

Dengan metode ceramah yang sangat lama, dapat berdampak pada peserta didik yang menganggap pelajaran IPS sulit, tidak menarik dan membosankan bagi peserta didik, bukan saja peserta didik tingkat atas tetapi juga peserta didik tingkat dasar. Hal ini sejalan dengan pemikiran Susanto (2014) bahwa "Pembelajaran IPS dianggap tidak bisa mengaplikasikan untuk mengetahui secara lebih jauh apa yang dipelajarinya, sehingga pembelajaran IPS juga dianggap hanya sekedar kepentingan sesaat, tanpa ada manfaat praktis dalam kehidupan sehari-hari”. Padahal pada pendidikan dasar inilah kita akan lebih mudah bahkan harus sedini mungkin menanamkan konsep-konsep pembelajaran IPS pada peserta didik. Pembelajaran harus dibuat dalam sebuah aktivitas yang dapat dimanfaatkan dan dapat digunakan dalam kehidupan sehari-hari. Maka dari itu, diadakan penelitian menggunakan pendekatan konstruktivis sosial yang bertujuan untuk meningkatkan hasil belajar peserta didik kelas IV di SD Kristen Advent Ambon.

\section{KAJIAN PUSTAKA}

\section{Pendekatan Konstruktivis Sosial}

Di dalam Pendekatan Konstruktivis Sosial (social constructivist approach) menekankan konteks sosial dalam belajar dan bahwa pengetahuan dibangun serta 
dikonstruksikan secara bersama-sama menurut Horowitz (dalam Santrock, 2009). Keterlibatan dengan orang lain akan menciptakan kesempatan bagi peserta didik untuk mengevaluasi dan memperbaiki pemahaman mereka, sebagaimana mereka terbuka pada pemikiran orang lain dan berpartisipasi dalam menciptakan pemahaman bersama menurut Gauvain (dalam Santrock, 2009). Dengan cara ini, pengalaman dalam konteks sosial memberikan mekanisme yang penting untuk perkembangan pemikiran peserta didik. Teori konstruktivis sosial dari Vygotsky memasukkan seorang anak secara sosial dalam konteks sosiohistoris. Pendekatan sosiohistoris menekankan pentingnya budaya dalam pembelajaran. Sebagai contoh, budaya dapat menentukan keterampilan apa yang penting (seperti keterampilan komputer, keterampilan komunikasi, keterampilan kerjasama tim, serta keterampilan dalam kesenian). Pendekatan konstruktivis sosial Vygotsky menekankan bahwa peserta didik-peserta didik membangun pengetahuan melalui interaksi sosial dengan orang lain (Santrock, 2009). Isi dari pengetahuan ini dipengaruhi oleh kultur tempat dimana peserta didik itu tinggal, yang berhubungan dengan bahasa, keyakinan, dan keterampilan. Guru harus menciptakan banyak peluang bagi peserta didik untuk belajar dengan membangun pengetahuan secara bersama-sama, baik dengan guru maupun dengan teman sebaya.

Pendekatan konstruktivis sosial juga menekankan Situated Cognition, yang merupakan asumsi penting dalam pendekatan konstruktivis sosial dalam kognisi yang merujuk pada ide bahwa berfikir ditempatkan (disituasikan) dalam konteks sosial dan fisik, bukan dalam fikiran individu menurut Gauvain (dalam Santrock, 2009). Dengan kata lain, pengetahuan ditanamkan dan dihubungkan dalam konteks dimana pengetahuan berkembang. Oleh karena itu, masuk akal untuk sebisa mungkin menciptakan situasi pembelajaran yang mendekati dunia nyata. Sebagai contoh, untuk memperluas pengetahuan dan pemahaman peserta didik tentang masalah-masalah sosial yang terjadi pada masyarakat, maka para peserta didik turun lapangan dengan didampingi oleh guru untuk memantau permasalahan sosial yang terjadi di daerah sekitar. Misalnya permasalahan sosial kemiskinan, kelaparan, lingkungan kumuh, pengangguran dll. Para peserta didik dibagi menjadi beberapa tim untuk langsung memantau kejadian sebenarnya tentang masalah yang diajukan oleh guru. Tim-tim tersebut akan berfikir bagaimana akar dari permasalahan yang terjadi dan memikirkan bagaimana solusi tentang masalah tersebut.

Pembelajaran dengan pendekatan konstruktivis sosial ini berpusat pada peserta didik dalam keaktifan berfikir dan ketrampilan memecahkan masalah sehingga tercipta pembelajaran yang mandiri sehingga hasil belajar peserta didik dapat meningkat. Pendekatan konstruktivisme memiliki beberapa prinsip diantaranya adalah: (1) pengetahuan dibangun oleh peserta didik secara aktif, (2) tekanan dalam proses belajar terletak pada peserta didik, (3) mengajar adalah membantu peserta didik belajar, (4) tekanan dalam proses belajar lebih pada proses bukan pada hasil akhir, (5) kurikulum menekankan partisipasi peserta didik, dan (6) pendidik adalah fasilitator. Suparmo (dalam Fitriani dkk, 2015). 


\section{Pendekatan Konstruktivis Sosial dalam Pembelajaran IPS di SD}

Pendekatan konstruktivisme sosial menekankan bahwa, kelompok dimana peserta didik berada, sangat menentukan proses pembentukan pengetahuan pada diri peserta didik. Melalui komunikasi dengan komunitasnya, pengetahuan seseorang dinyatakan kepada orang lain sehingga pengetahuan itu mengalami verifikasi, dan penyempurnaan (Adisusilo, 2010). Selain itu, melalui komunikasi seseorang memperoleh informasi atau pengetahuan baru dari masyarakatnya. Vygotsky menyatakan bahwa kematangan fungsi mental anak justru terjadi lewat proses kerjasama dengan orang lain, seperti dinyatakan oleh Newman (1993: 62) sebagai berikut: "The maturation of the child's higher mental functions occurs in this cooperative process, that is, it occurs through the adult's assistance and participation". Konstruktivisme sosial menekankan bahwa pembentukan ilmu pengetahuan merupakan hasil pembentukan individu bersama-sama dengan masyarakat sekitarnya. Bahkan Piaget menulis sebagai berikut (Fosnot (ed), 1996: 18): "There is no longer any need to choose between the primacy of the social or that of the intellect; the collective intellect is the social equilibrium resulting from the interplay of the operations that enter into all cooperation".

Pendidikan Ilmu Pengetahuan Sosial menurut Somantri (dalam Sapriya, 2009:11) merupakan seleksi dari disiplin ilmu-ilmu sosial dan humaniora, serta kegiatan dasar manusia yang mengorganisasikan dan disajikan secara ilmiah dan psikologis untuk tujuan pendidikan. IPS juga salah satu alternatif untuk menjawab pertanyaan yang muncul khususnya dikalangan masyarakat, pakar, praktisi dan akademisi PIPS dan sekaligus sebagai fasilitas sumber belajar untuk meningkatkan mutu pendidikan di tanah air (Sapriya, 2009:3). Menurut Supardan (2015) "Tujuan utama dari mata pelajaran Ilmu Pengetahuan Sosial yaitu untuk mengembangkan peserta didik menjadi warga negara yang memiliki pengetahuan, nilai dan sikap, serta keterampilan yang memadai untuk berperan serta dalam kehidupan demokrasi.

Selain itu menurut Sumaatmadja (2006) pendidikan IPS adalah mata pelajaran atau mata kuliah yang mempelajari kehidupan sosial yang kajiannya mengintegrasikan bidang ilmu-ilmu sosial dan humaniora. Adapun menurut Winataputra (2003:132) berpendapat bahwa pendidikan IPS merupakan program pendidikan sosial pada jalur pendidikan sekolah dan jalur sekolah yang mencakup mata pelajaran pendidikan pancasila dan kewarganegaraan (PPKN), IPS terpadu di sekolah dasar (SD) dan Paket A Luar Sekolah; IPS terkolerasi di Sekolah Lanjutan Tingkat Pertama (SLTP) dan Paket B Luar Sekolah, yang di dalamnya mencakup materi geografi, sejarah, dan ekonomi koperasi, dan IPS terpisah di Sekolah Menengah Umum (SMU) yang terdiri atas mata pelajaran geografi, sejarah, dan ekonomi dan tata negara. Sehubungan dengan ini,penelitian akan dilaksanakan pada peserta didik kelas IV dengan standar kompetensi 2. Mengenal sumber daya alam, kegiatan ekonomi, dan kemajuan teknologi di lingkungan kabupaten/kota dan provinsi. Kompetensi dasar 2.4 Mengenal permasalahan sosial di daerahnya. 


\section{METODOLOGI}

Penelitian ini merupakan penelitian tindakan kelas yang dilaksanakan pada bulan April 2017. Penelitian tindakan kelas ini memiliki tujuan untuk memperbaiki atau meningkatkan hasil pembelajaran di kelas melalui suatu tindakan (treatment) tertentu dalam satu atau beberapa siklus sesuai yang dibutuhkan. Subjek dalam penelitian ini adalah peserta didik kelas IV SD Kristen Advent Ambon yang berjumlah 15 orang. Pelaksanaan penelitian dilakukan dalam 2 siklus, setiap siklus terdiri dari tahapan 1) perencanaan (plan), 2) pelaksanaan (action), 3) pengamatan (observation), 4) refleksi (reflection) Kemmis dan Taggart, 1990 (dalam Akbar, 2009).

Pertama, perencanaan. Dalam perencanaan, peneliti menyiapkan perangkat pembelajaran seperti silabus, RPP, bahan ajar, LKS, soal tes evaluasi dan lembar observasi.

Kedua, pelaksanaan. Pelaksanaan tindakan dilaksanakan 2 pertemuan setiap siklusnya. Kegiatan pembelajaran dilakukan mengikuti petunjuk yang ada dalam RPP berdasarkan sintaks pembelajaran menggunakan pendekatan konstruktivis sosial. Sintaks dari pendekatan konstruktivis sosial meliputi: 1) guru menjelaskan tujuan pembelajaran, 2) guru membagi peserta didik ke dalam beberapa kelompok dan setiap kelompok memiliki satu peserta didik yang dianggap mampu (pintar) dalam penyelesaian masalah, 3) guru memberikan materi yang berbeda pada masing-masing kelompok berdasarkan konteks sosial, 4) peserta didik menyelesaikan permasalahan dengan bertukar pikiran dengan teman satu kelompok, teman yang hanya diam dan tidak memahami harus dibantu oleh peserta didik yang lebih mampu, 5) seluruh peserta didik diharapkan berpartisipasi dalam diskusi kelompok, 6) guru membantu peserta didik yang belum memahami materi pembelajaran, 7) setiap peserta didik di dalam kelompok mengemukakan pendapatnya ketika sesi diskusi selesai untuk dibacakan pada kelompok lain, 8) kelompok lain menanggapi dan memberikan masukan terhadap pekerjaan kelompok.

Ketiga, observasi. Selama proses pembelajaran berlangsung, pengamatan dilakukan dengan menggunakan lembar observasi. Selama pengamatan observer 1 atau guru mengamati pelaksanaan sintaks pembelajaran yang dilakukan oleh peneliti dan observer 2 (teman sejawat) mengamati aktivitas peserta didik selama proses pembelajaran berlangsung.

Keempat, refleksi. Proses refleksi dilakukan pada saat semua langkah dilaksanakan sampai evaluasi proses pembelajaran akhir siklus tindakan, peneliti bersama guru yang berperan sebagai observer melakukan refleksi untuk mengevaluasi kelemahan dan kekuatan yang ditemukan selama proses pembelajaran berlangsung. Tingkat kecermatan dan ketelitian observasi di upayakan akurat karena melalui hasil refleksi tersebut diharapkan pada siklus II dapat dilakukan perbaikan yang lebih tepat. Pelaksanaan siklus II mengikuti prosedur pada siklus I, dengan memperhatikan catatan-catatan perbaikan dan perubahannya dalam proses pembelajaran berdasarkan hasil refleksi siklus I.

Teknik pengumpulan data. Merupakan langkah paling strategis dalam penelitian untuk mendapatkan data. Sedangkan pengumpulan data yaitu cara-cara yang 
dilakukan peneliti untuk mendapatkan data yang tepat, valid dan riil dengan menggunakan suatu teknik pengumpulan data secara prosedur dan sistematis secara obyektif. Data penelitian bersumber dari interaksi guru dan peserta didik dalam pembelajaran IPS dan berupa tindakan belajar atau perilaku belajar yang dihasilkan dari tindakan pemberian permasalahan yang diselesaikan secara bersamasama dengan peserta didik lain dengan pendekatan konstruktivis sosial.

\section{HASIL PENELITIAN}

\section{Siklus I}

Penelitian pada siklus I dilaksanakan dengan memperhatikan RPP yang telah dibuat dan menjalankan aktivitas penelitian dengan sintaks pendekatan konstruktivis sosial, yakni pertama peneliti mengemukakan tujuan pembelajaran yang harus dicapai, peneliti lalu memilih 5 peserta didik yang di anggap lebih pandai dari yang lain sebagai ketua kelompok, peneliti membagi peserta didik ke dalam 5 kelompok masing-masing memiliki 3 anggota dalam kelompoknya. Peneliti membagikan materi tentang permasalahan-permasalahan sosial yang terjadi di daerah sekitar. Masingmasing kelompok memiliki permasalahan yang harus dipecahkan, setiap peserta didik harus mengemukakan pendapatnya di dalam kelompok untuk di tulis di dalam LKS yang diberikan peneliti. Setelah selesai diskusi kelompok, setiap anggota di kelompok secara bergantian mengemukakan pendapatnya dan di perhatikan oleh kelompok lain untuk mendapat tanggapan atau tambahan. Kegiatan ini terus dilakukan sampai semua kelompok mendapatkan giliran untuk mempresentasikan hasil kerjanya. Kegiatan pembelajaran ini dilaksanakan selama 2 kali pertemuan pada siklus I. Setelah beberapa kelompok sudah mengemukakan pendapatnya, ada beberapa anggota kelompok yang tidak mengemukakan pendapatnya. Hal ini tidak dibiarkan saja oleh peneliti, peneliti memberikan bantuan terhadap kelompok yang belum maksimal dalam pendapatnya sehingga semua menjadi lebih jelas di dalam proses pembelajaran. Setelah semua selesai, peneliti memberikan tes akhir siklus I kepada seluruh peserta didik untuk mengetahui sejauh mana materi yang telah didiskusikan diserap dengan baik oleh peserta didik.

Hasil tes siklus I menunjukkan bahwa meskipun para peserta didik pada saat diskusi kelompok sangat antusias tetapi kenyataannya masih banyak yang belum memenuhi nilai Kriteria Ketuntasan Minimal (KKM) sebesar 65. Pada Siklus I pertemuan 1, sebanyak 8 orang peserta didik belum mencapai KKM yang ditentukan atau sekitar 53,3\% peserta didik belum tuntas, sedang 7 orang peserta didik telah memenuhi standar KKM yang telah di tentukan atau sekitar 46,6\% peserta didik telah tuntas di atas KKM. Pada Siklus I pertemuan 2, terlihat ada peningkatan 3 orang peserta didik yang semula tidak tuntas 8 orang pada pertemuan 2 tinggal 5 orang saja yang belum tuntas KKM. Hasil tes siklus I dapat dilihat pada tabel di bawah ini: 
Tabel 1. Hasil Tes Siklus I

\begin{tabular}{|c|c|c|c|c|c|c|c|}
\hline \multirow{2}{*}{ No } & \multicolumn{3}{|c|}{$\begin{array}{c}\text { Pama } \\
\text { Peserta } \\
\text { Didik }\end{array}$} & \multicolumn{3}{|c|}{ I } & \multicolumn{3}{c|}{ II } \\
\hline & & Nilai & Tuntas & $\begin{array}{c}\text { Tidak } \\
\text { Tuntas }\end{array}$ & Nilai & Tuntas & $\begin{array}{c}\text { Tidak } \\
\text { Tuntas }\end{array}$ \\
\hline 1 & FT & 65 & $\checkmark$ & & 65 & $\checkmark$ & \\
\hline 2 & CA & 50 & & $\checkmark$ & 58 & & $\checkmark$ \\
\hline 3 & NV & 70 & $\checkmark$ & & 78 & $\checkmark$ & \\
\hline 4 & HI & 50 & & $\checkmark$ & 55 & & $\checkmark$ \\
\hline 5 & PP & 65 & $\checkmark$ & & 68 & $\checkmark$ & \\
\hline 6 & CV & 55 & & $\checkmark$ & 63 & & $\checkmark$ \\
\hline 7 & RD & 60 & & $\checkmark$ & 80 & $\checkmark$ & \\
\hline 8 & RE & 65 & $\checkmark$ & & 71 & $\checkmark$ & \\
\hline 9 & BT & 60 & & $\checkmark$ & 65 & $\checkmark$ & \\
\hline 10 & MR & 50 & & $\checkmark$ & 54 & & $\checkmark$ \\
\hline 11 & JS & 65 & $\checkmark$ & & 65 & $\checkmark$ & \\
\hline 12 & LP & 40 & & $\checkmark$ & 70 & $\checkmark$ & \\
\hline 13 & KK & 65 & $\checkmark$ & & 60 & & $\checkmark$ \\
\hline 14 & AT & 70 & $\checkmark$ & & 67 & $\checkmark$ & \\
\hline 15 & RL & 55 & & $\checkmark$ & 65 & $\checkmark$ & \\
\hline Jumlah & & 885 & & & 984 & \\
\hline Nilai rata-rata & & $59 \%$ & & & $65,6 \%$ & \\
\hline
\end{tabular}

Hasil pengamatan oleh observer 1 mendapati bahwa peneliti dalam membimbing peserta didik dalam diskusi masih belum maksimal, terbukti dari masih banyak peserta didik yang bermain sendiri saat diskusi sedang berlangsung. Peneliti juga kurang memperhatikan waktu yang ditentukan, sehingga pada saat waktu habis tetapi proses pembelajaran belum selesai tepat waktu. Sedangkan pengamatan dari observer 2 yang mengamati peserta didik, masih banyak yang belum mengemukakan pendapatnya karena peserta didik ada yang masih malu-malu dan ada yang tidak menguasai materi. Pada akhirnya masih banyak yang pasif sehingga harus dituntun oleh peneliti untuk mengemukakan pendapatnya.

Setelah melihat fakta yang terjadi pada saat penelitian di dalam kelas dan tingkat ketuntasan klasikal kelas hanya mencapai 65,6\%, maka guru dan peneliti duduk bersama untuk melakukan refleksi dari pelaksanaan siklus I, refleksi sebagai berikut: 1) peneliti belum membimbing peserta didik secara maksimal sehingga masih banyak peserta didik yang hanya diam saja di dalam diskusi, 2) peneliti kehabisan banyak waktu sehingga pada saat waktu habis pembelajaran masih berlangsung, 3) peneliti belum maksimal untuk memberikan penjelasan yang mudah dipahami kepada peserta didik, 4) peneliti masih membiarkan ketika peserta didik yang pandai mendominasi diskusi kelompok dan mengeluarkan pendapat secara terus-menerus 
tanpa memberikan kesempatan pada anggota yang lain. Dari hasil refleksi tersebut perlu diadakan penlitian kembali pada siklus ke II agar kesalahan-kesalahan pada siklus I dapat diperbaiki dan hasil belajar peserta didik dapat meningkat.

\section{Siklus II}

Siklus II dilaksanakan sesuai dengan sintaks seperti siklus I. Dalam siklus kedua ini guru mengupayakan beberapa hal yaitu: 1) membimbing secara maksimal pada seluruh perserta didik yang ada di kelas pada saat diskusi agar seluruh peserta didik dapat mengemukakan pendapatnya seperti peserta didik lain, peneliti akan meminta bantuan dari guru dan juga teman sejawat untuk membimbing peserta didik yang membutuhkan bantuan, 2) peneliti meminta teman sejawat untuk mengingatkan ketika waktu akan segera habis, 3) peneliti akan memberikan penjelasan yang konkrit disertai contoh agar peserta didik dapat memahami diskusi yang sedang dijalankan, 4) peneliti bertindak adil kepada seluruh peserta didik di dalam kelas pada saat diskusi berlangsung, yang pandai dan yang biasa dalam hal kemampuan semua harus mengemukakan pendapatnya dengan cara peserta didik yang lebih pandai mengajari peserta didik yang kurang memahami dan masih malu untuk mengemukakan pendapat.

Setelah tes siklus II diberikan kepada peserta didik pada pertemuan kedua, peneliti dan guru kemudian mengoreksi hasil belajar peserta didik. Adapun hasil yang diperoleh peserta didik sudah mengalami perubahan yang signifikan dibandingkan dengan siklus I yakni sebagai berikut: pada siklus II rata-rata ketuntasan klasikal kelas menjadi $84 \%$ dan sebanyak 15 peserta didik nilai yang dihasilkan sudah mencapai KKM yang ditentukan sehingga sudah 100\% peserta didik yang lolos KKM. Hasil refleksi siklus II menyebutkan bahwa peneliti sudah melaksanakan pembimbingan dengan bantuan guru dan teman sejawat terhadap peserta didik yang belum mengemukakan pendapat, teman sejawat sudah memberi isyarat pada saat 15 menit sebelum waktu habis sehingga peneliti bersiap-siap untuk menyelesaikan penelitian sebelum waktu habis, peneliti sudah menjelaskan dengan maksimal dengan contoh-contoh konkrit yang dapat dengan mudah untuk dicerna peserta didik, dan yang terakhir peneliti sudah bertindak adil terhadap seluruh peserta didik yang kurang maupun yang pandai seluruhnya sudah dapat mengemukakan pendapatnya meski harus dengan bantuan peneliti ataupun peserta didik yang lain.

Tabel 1. Hasil Tes Siklus II

\begin{tabular}{|c|c|c|c|c|c|c|c|}
\hline \multirow{2}{*}{ No } & $\begin{array}{c}\text { Nama } \\
\text { Peserta } \\
\text { didik }\end{array}$ & \multicolumn{3}{|c|}{ Pertemuan } & \multicolumn{3}{c|}{ Pertemuan } \\
I & \multicolumn{2}{|c|}{} & \multicolumn{3}{c|}{} \\
\hline & & Nilai & Tuntas & $\begin{array}{c}\text { Tidak } \\
\text { Tuntas }\end{array}$ & Nilai & Tuntas & $\begin{array}{c}\text { Tidak } \\
\text { Tuntas }\end{array}$ \\
\hline 1 & FT & 85 & $\sqrt{ }$ & & 95 & $\sqrt{ }$ & \\
\hline 2 & CA & 70 & $\sqrt{ }$ & & 88 & $\sqrt{ }$ & \\
\hline
\end{tabular}




\begin{tabular}{|c|c|c|c|c|c|c|c|}
\hline 3 & $\mathrm{NV}$ & 90 & $\sqrt{ }$ & & 95 & $\sqrt{ }$ & \\
\hline 4 & $\mathrm{HI}$ & 67 & $\sqrt{ }$ & & 75 & $\sqrt{ }$ & \\
\hline 5 & $\mathrm{PP}$ & 89 & $\sqrt{ }$ & & 90 & $\sqrt{ }$ & \\
\hline 6 & $\mathrm{CV}$ & 60 & & $\sqrt{ }$ & 69 & $\sqrt{ }$ & \\
\hline 7 & $\mathrm{RD}$ & 80 & $\sqrt{ }$ & & 86 & $\sqrt{ }$ & \\
\hline 8 & $\mathrm{RE}$ & 85 & $\sqrt{ }$ & & 80 & $\sqrt{ }$ & \\
\hline 9 & BT & 80 & $\sqrt{ }$ & & 88 & $\sqrt{ }$ & \\
\hline 10 & MR & 70 & $\sqrt{ }$ & & 78 & $\sqrt{ }$ & \\
\hline 11 & JS & 85 & $\sqrt{ }$ & & 90 & $\sqrt{ }$ & \\
\hline 12 & LP & 60 & & $\sqrt{ }$ & 70 & $\sqrt{ }$ & \\
\hline 13 & $\mathrm{KK}$ & 78 & $\sqrt{ }$ & & 87 & $\sqrt{ }$ & \\
\hline 14 & $\mathrm{AT}$ & 80 & $\sqrt{ }$ & & 86 & $\sqrt{ }$ & \\
\hline 15 & RL & 80 & $\sqrt{ }$ & & 83 & $\sqrt{ }$ & \\
\hline \multicolumn{2}{|c|}{ Jumlah } & & \multicolumn{2}{|c|}{1159} & \multicolumn{3}{|c|}{1260} \\
\hline \multicolumn{2}{|c|}{ Nilai rata-rata } & & \multicolumn{2}{|c|}{$77,2 \%$} & \multicolumn{3}{|c|}{$84 \%$} \\
\hline
\end{tabular}

\section{PEMBAHASAN}

Pada siklus I pertemuan I para peserta didik diberikan materi tentang permasalahan-permasalahan sosial yang terjadi di lingkungan sekitar, peneliti memberikan 5 persoalan untuk diselesaikan 5 kelompok yang telah di pilih. 5 persoalan yang digunakan dalam penelitian ini yaitu masalah pengangguran, masalah kekerasan seksual, masalah kejahatan, masalah kemiskinan, dan masalah kebersihan lingkungan. Lima persoalan ini diminta untuk di identifikasi persoalannya dan dicarikan solusi penanganannya. Pada pertemuan kedua siklus I seluruh peserta didik mendapatkan soal tes siklus I yang hasilnya belum begitu memuaskan yaitu dari 15 peserta didik yang mengerjakan soal tersebut masih ada 8 peserta didik yang belum tuntas atau 53,3\% peserta didik belum tuntas, sedang 7 orang peserta didik telah memenuhi standar KKM yang telah di tentukan atau sekitar 46,6\% peserta didik telah tuntas di atas KKM. Pada siklus I dari hasil refleksi masih menyebutkan bahwa peneliti masih belum maksimal dalam memberikan penjelasan kepada peserta didik, peneliti kehabisan waktu pada saat melakukan penelitian, peneliti belum memberikan penjelasan dengan bahasa yang mudah dipahami menggunakan contoh-contoh konkrit, dan peneliti masih membiarkan peserta didik yang pandai mendominasi diskusi kelompok.

Pada siklus II pertemuan 1 dan 2 masih dilanjutkan dengan materi persoalan lain yang timbul setelah adanya permasalahan sosial dan bagaimana pencegahannya. Setelah selesai diskusi pada pertemuan 2 siklus 2 dilaksanakan tes akhir. Pada tes kedua ini peserta didik mendapatkan ketuntasan klasikal rata-rata sebesar $84 \%$ dan seluruh peserta didik mendapatkan nilai di atas KKM yang ditentukan meski masih ada yang nilainya pas dengan KKM. Dari hasil refleksi siklus I, semua kekurangan itu telah diperbaiki di siklus II sehingga peneliti telah memberikan seluruh kemampuannya untuk membantu peserta didik yang lemah dalam hal memahami 
materi. Hal ini mengakibatkan seluruh peserta didik memahami materi yang disampaikan dan berdampak pada peningkatan hasil belajar peserta didik.

Dengan demikian terjadi peningkatan secara klasikal pada peserta didik dari siklus I pertemuan 1 ke pertemuan 2 sebesar 6,6\% dari siklus I pertemuan 1 sebesar $59 \%$ menjadi $65,6 \%$ pada pertemuan 2 . Sedangkan ketuntasan klasikal peserta didik pada siklus II bertambah menjadi $6,8 \%$ yaitu pada siklus II pertemuan 1 sebesar $77,2 \%$ menjadi $84 \%$ pada pertemuan 2. Pada siklus II seluruh peserta didik tuntas dengan nilai di atas KKM yakni 15 peserta didik atau 100\% tuntas. Maka penelitian tindakan kelas dengan menerapkan pendekatan konstruktivis sosial dikatakan berhasil. Hal ini sejalan dengan pendapat Sumarno (2011) menjelaskan mengenai penerapan pendekatan konstruktivisme terhadap hasil belajar yakni:

Di dalam pembelajaran konstruktivisme terdapat dua perubahan konsep yang terjadi pada peserta didik yaitu perubahan konsep yang kuat dan perubahan konsep yang lemah. Perubahan konsep yang kuat terjadi apabila seseorang mengadakan akomodasi terhadap konsep yang telah ia punya ketika berhadapan dengan fenomena yang baru. Sedangkan perubahan konsep yang lemah terjadi apabila orang tersebut mengadakan asimilasi konsep yang lama ketika berhadapan dengan fenomena yang baru.

Penelitian ini juga mendukung beberapa penelitian terdahulu yang menggunakan pendekatan konstruktivis dalam penelitiannya, diantaranya dari penelitian pengembangan oleh Fitriani dkk (2015), diambil kesimpulan dalam proses pembelajaran dengan menggunakan media interaktif berorientasi konstruktivisme sangat berhasil dalam meningkatkan aktifitas mahapeserta didik. Penelitian yang kedua yakni dari Jasumayanti dan Marli (2013) Hasil penelitian menunjukkan bahwa terdapat korelasi yang siginifikan antara penerapan pendekatan konstruktivisme dengan hasil belajar peserta didik dalam pembelajaran IPS kelas IV Sekolah Dasar Negeri 35 Pontianak Selatan. Penelitian ini juga mendukung penelitian Disertasi dari Arifin (2017), dari hasil analisis data diperoleh kesimpulan bahwa aktivitas belajar dan peningkatan hasil belajar peserta didik yang dibelajarkan dengan pendekatan konstruktivisme menggunakan metode brainstorming lebih tinggi dibanding yang dibelajarkan dengan pendekatan konstruktivisme dengan metode konvensional serta ada korelasi antara aktivitas belajar dengan peningkatan hasil belajar.

\section{KESIMPULAN}

Berdasarkan pada hasil dan pembahasan dapat disimpulkan bahwa pendekatan konstruktivis sosial dapat meningkatkan hasil belajar peserta didik di kelas IV SD Kristen Advent. Hal ini terbukti dari hasil belajar yang semula hanya 7 peserta didik saja yang tuntas dari siklus I, selanjutnya seluruh peserta didik tuntas pada siklus II. Peneliti melakukan hal yang sangat bagus dengan memberikan pemahaman dengan sabar kepada peserta didik yang belum mampu mengemukakan pendapatnya, apabila belum memahami diberikan contoh-contoh yang mudah dipahami sehingga seluruh peserta didik dapat menyelesaikan soal tes pada siklus II meski tidak seluruhnya 
benar. Tetapi seluruh peserta didik sudah mendapatkan hasil di atas KKM yang ditentukan yaitu 65 .

Demikian kesimpulan dari penelitian ini bahwa penerapan pendekatan konstruktivis sosial yang dikemukakan oleh Lev Vygotsky dapat membantu peserta didik dalam memahami materi, peserta didik yang tidak bisa dengan cepat memahami materi dapat berdiskusi dengan teman sekelompok, apabila teman satu kelompok sudah maksimal dalam penjelasannya dan peserta didik masih belum memahami maka peneliti bertindak untuk penjelas terakhir sampai seluruh peserta didik memahami materi.

\section{DAFTAR PUSTAKA}

Adisusilo, Sutarjo. "Konstruktivisme dalam Pembelajaran." Tersedia pada: http://veronikacloset. files. wordpress. com/2010/06/konstruktivisme. pdf (diakses tanggal 18 Agustus 2017).

Akbar, S, \& Z, Luluk, F. 2009. Prosedur Penyusunan Laporan dan Artikel: Hasil Penelitian Tindakan Kelas. Yogyakarta: Cipta Media Aksara.

Arifin, Ilham. Penerapan Pendekatan Konstruktivisme Dengan Metode Brainstorming (Curah Pendapat) Untuk Meningkatkan Hasil Belajar dan Aktivitas Belajar Kimia Peserta Didik. Diss. UNIMED, 2017.

Fitriani, Vivi, Yuni Ahda, and Lufri Lufri. "Pengembangan Media Pembelajaran Interaktif Berorientasi Konstruktivisme Pada Materi Gastrulasi Dalam Mata Kuliah Perkembangan Hewan." Jurnal Kolaboratif Vol. 2 No.2 (2015).

Fosnot (1996).Enquiring Teachers. Enquiring Learners. A constructivist Approach for Teaching. New York: Columbia University

Jasumayanti, Eka, and Suhardi Marli. "Korelasi antara pendekatan konstruktivisme dengan hasil belajar peserta didik pada pembelajaran IPS SD." Jurnal Pendidikan dan Pembelajaran Vol. 2 No.3 (2013).

Kemmis, S., \& McTaggart, R. (Eds.). (1990). The Action Research Reader. Victoria: Deakin University.

Newman, F. et al.(1993).Lev Vygotsky,Rrevolutionary Scientist.London and New

York:Routledge

Santrock, J.W. 2009. Psikologi Pendidikan. Jakarta : Salemba Humanika.

Sapriya. 2009. Pendidikan IPS. Bandung : Remaja Rosdakarya.

Sumaatmadja, Nursid. 2006. Metodologi Pengajaran ilmu Pengetahuan Sosial (IPS). Bandung: Alumni.

Sumarno, Alim (2011) (http://blog.elearning.unesa.ac.id/alim-sumarno/hubungankonstruktivismedengan-pendidikan),

Supardan, Dadang. 2015. Pembelajaran Ilmu Pengetahuan Sosial (Perspektif Filosofi dan Kurikulum). Jakarta: Bumi Aksara.

Susanto, Ahmad. 2014. Pengembangan Pembelajaran IPS di SD. Jakarta: Prenatamedia Group.

Winataputra, Udin. 2003. Strategi Belajar Mengajar. Pusat Penerbitan Universitas Terbuka. Jakarta. 